\section{A importância da formalização da política para a garantia do direito à saúde do doente mental}

The importance of formalizing policies to ensure the right to health of the mentally ill

\section{Sueli Gandolfi Dallari ${ }^{4}$}

A assunção dos princípios do Movimento da Reforma Psiquiátrica no cotidiano da elabora ção e da gestão da política de saúde mental nas três esferas de governo, no Brasil, deve ser moti vo de satisfação para todos aqueles que milita ram e continuam a fazê lo no seio daquele movimento. Isto porque a garantia de um direi to exige a possibilidade de sua afirmação, inclu sive, pelo Poder Judiciário. Assim, apenas uma política pública sanitária que tenha sido elabora da com a participação popular e formalizada em diferentes suportes legais, nos Municípios, nos Estados e na União, poderá ser reconhecida como um direito vigente, no Brasil.
No caso da saúde mental, pode se afirmar que a Constituição brasileira contém vários dis positivos que orientam a formulação e a imple mentação da política destinada à prestação de ações e serviços para sua garantia. Certamente o mais importante deles diz respeito à participação popular, que funda a democracia representativa e direta, características do Estado Democrático de Direito, inscrito em seu artigo inaugural. E o Movimento da Reforma Psiquiátrica Brasileira, nascido ainda em meados da década de setenta do último século, testemunha a efervescência das discussões públicas a orientar as opções políticas na matéria. A curiosa história dos dois primei ros Congressos de Trabalhadores de Saúde Men tal de São Paulo, em 1985, comprova com lar gueza de argumentos a afirmação anterior: nas cido de uma real oposição, ele consegue ser "o marco de articulação de diferentes movimentos sociais em torno da Reforma Psiquiátrica, parti cularmente de São Paulo, Rio, Minas Gerais".

A importância da participação popular ado tada na construção do novo Estado será, então, reforçada em diversos dispositivos, cuidando especificamente do processo legislativo ou da construção de políticas setoriais. Estava claro, tanto para os teóricos quanto para os movimen tos sociais organizados, que o "direito" deveria ter gênese democrática e que seria fruto, então, da combinação e da mediação recíproca entre a soberania do povo juridicamente institucionali zada e a soberania do povo não institucionaliza da. Considerava se que tal equilíbrio, como na lição de Habermas, implicava "a preservação de espaços públicos autônomos, a extensão da par ticipação dos cidadãos, a domesticação do po der das mídias e a função mediadora dos parti dos políticos não estatizados"'. Assim, por exem plo, a participação popular na Administração de veria ser considerada um procedimento eficiente "ex ante" para legitimar as decisões que apreci adas conforme seu conteúdo normativo atuam como atos legislativos ou judiciários. Não havia dúvida de que apenas a manutenção do espaço jurídico público permitiria superar a velha opo sição entre direitos formais e reais, entre direitos políticos e sociais.
${ }^{4}$ Núcleo de Pesquisas em Direito Sanitário, Faculdade de Saúde Pública, Universidade de São Paulo. sdallari@usp.br 
Certamente o setor saúde foi o que primeira e mais intensamente se dedicou à instituição dos espaços públicos autônomos na organização brasileira. Assim, a própria Constituição estabe lece como uma das diretrizes para a organização do sistema de saúde a participação da comuni dade em todas as ações e serviços de saúde (CF. art. 198, III). A legislação nacional que regula mentou esse dispositivo, conhecida como Lei Orgânica da Saúde (Lei federal no 8080/90 e Lei federal no 8142/90), institucionalizou duas ins tâncias de participação popular: a conferência e o conselho de saúde. E a II Conferência Nacional de Saúde Mental, realizada já em 1992, revela que o Movimento da Reforma Psiquiátrica Brasilei ra se apropriou adequadamente do instrumento legal, proporcionando a intensa participação dos segmentos sociais envolvidos. Fato que se repete em 2001, quando da III Conferência Nacional de Saúde Mental.

Além disso, a Constituição da República, de 1988, reforçou a estrutura federativa do Estado, reconhecendo competências próprias às três es feras de governo, mas inovando na definição das hipóteses do chamado "federalismo de coopera ção”. Assim, ela atribuiu à União, no campo sani tário, a competência para editar normas gerais de proteção e defesa da saúde, que deverão ser complementadas por regras dos Estados e dos Municípios, nesta ordem hierárquica (CF art. 24, $\$ 1^{\circ}$ e $2^{\circ} \mathrm{c} / \mathrm{c}$ art. 30, II). E, ainda na área da coope ração, ela previu uma esfera de competências comuns, que em saúde implicam a responsabili dade solidária de todos os entes da federação: União, Estados, Distrito Federal e Municípios por "cuidar da saúde" (CF art. 23, II). Novamente o Movimento da Reforma Psiquiátrica Brasileira agiu em perfeita sintonia com os ditames consti tucionais, apresentando, já em 1898, um projeto do que viria a ser conhecido como a Lei da Re forma Psiquiátrica, que foi aprovado apenas mais de uma década depois, transformando se na Lei federal no 10.216/2001. Enquanto essa nor ma geral de proteção e defesa da saúde mental que impediria a construção ou a contratação de novos hospitais psiquiátricos pelo poder públi co, direcionava os recursos públicos para a cria ção de "recursos não manicomiais de atendi mento" e obrigava a comunicação das interna ções compulsórias à autoridade judiciária era discutida, vários Estados aprovaram legislação semelhante, valendo se do previsto mesmo arti go 24 da Constituição da República. De fato, diz o parágrafo $3^{\circ}$ desse artigo que "inexistindo lei federal sobre normas gerais, os Estados exerce rão a competência legislativa plena, para atender a suas peculiaridades". E a superveniência da Lei da Reforma Psiquiátrica suspendeu a eficácia dessas leis estaduais apenas no que lhe foram contrárias (CF art. 24, \$ 4\%).

As políticas públicas devem, como visto, as segurar a participação popular na Administra ção para legitimar suas decisões normativas. É preciso que todo o arcabouço normativo, so bretudo o sanitário, seja construído com a efeti va participação de todos os interessados. E neste ponto cabe uma crítica importante ao processo de formalização da política de saúde mental no Brasil. Com efeito, vários suportes normativos veicularam a implementação das medidas prio ritárias elencadas nas Conferências e previstas na legislação durante a primeira década dos anos 2000. Nenhuma dessas portarias, contudo, faz referência ao processo da participação popular que as legitima. E note se que não há qualquer dúvida que tanto os Centros de Atenção Psicos social (CAPS), quanto os Serviços Residenciais Terapêuticos em Saúde Mental (previstos, res pectivamente, nas Portarias no 336, de 19 de feve reiro de 2002, e no 106, de 11 de fevereiro de 2004, ambas do Gabinete do Ministro da Saúde), re presentam importantes recursos não manicomi ais, que permitem o efetivo cumprimento da Lei, especialmente no que respeita à indicação da in ternação (lei 10 216/2001, art. 4º). O que existe, sim, é um menosprezo formal pelo processo de participação popular na feitura da norma, que o torna invisível para um juiz que deva apreciar eventual disputa a respeito do uso desses recur sos terapêuticos.

É fato que uma política de saúde mental, de senhada em suas grandes linhas pelo Movimen to da Reforma Psiquiátrica Brasileira, vem sendo implementada pelos serviços de saúde em todos os níveis da federação, tendo sido previstos obri gações e recursos financeiros para isso nas nor mas que regem as relações internas entre União, Estados e Municípios. Existem, porém, novos segmentos populacionais que ainda não foram adequadamente amparadas pelas ações e servi ços atualmente previstos na política e disponí veis para os necessitados. Isso não deve significar que a força democratizante de gestões de Municí pios, Estados e União esteja "fagocitando" o Movimento da Reforma Psiquiátrica Brasileira, como supõe Ana Pitta no denso artigo "Reforma psiquiátrica no Brasil: Ideias, atores e institui ções políticas”. Certamente não deve ser essa a conclusão frente ao processo de formalização da política de saúde mental que veiculou. Importa 
agora controlar a execução da política, empre gando tanto a participação popular direta quan to, eventualmente, o recurso ao Poder Judiciário para garantir sua realização conforme a vontade dos interessados manifestadas nos espaços pú blicos autônomos. Esse é o novo desafio do Movimento da Reforma Psiquiátrica Brasileira.

\section{Referências}

1. Habermas J. Droit et démocratie: entre faits et nor mes. Paris: Gallimar; 1996. 